\title{
Enriquecimento de microrganismos metanotróficos a partir de lodo de reator UASB tratando esgotos domésticos
}

\author{
Enrichment of methanotrophic microorganisms from \\ sludge of UASB reactor treating domestic sewage
}

\section{Luciene Alves Batista Siniscalchi', Isabel Campante Cardoso Vale², Jéssica Dell 'Isola Antunes², Carlos Augusto de Lemos Chernicharo ${ }^{3}$, Juliana Calábria de Araújo ${ }^{4}$}

\section{RESUMO}

Nesse estudo, microrganismos metanotróficos foram enriquecidos a partir de lodo proveniente de um reator UASB tratando esgotos domésticos em reator em batelada sequencial (RBS) com meio autotrófico contendo nitrito e nitrato. As eficiências médias de remoção de nitrito e nitrato foram de $68 \%$ e $53 \%$, respectivamente, provavelmente devido à atividade heterotrófica desnitrificante. A detecção de arquéias dos grupos ANME-I e ANME-II foram realizadas por PCR durante todo período de cultivo. A estrutura da comunidade microbiana presente no inóculo e enriquecida no RBS após 100 dias de operação foi estudada por pirosequenciamento. Os resultados das análises demonstraram que a comunidade enriquecida no reator foi diferente à inoculada. Os filos dominantes no inóculo foram Synergistestes, Firmicutes e Euryarchaeota, ao passo que na biomassa enriquecida Planctomycetes, Verrucomicrobia, Chloroflexi e Proteobacteria predominaram. As condições de cultivo do RBS reduziram a abundância de Methanobacterium (8\% para 1\%) e selecionaram bactérias metanotróficas como Methylocaldum. Methylocistis e Methylosinus. As sequências de Methylocaldum sp. apresentaram abundância relativa de $2.5 \%$. A presença e elevada predominância do filo Verrucomicrobia na biomassa enriquecida do RBS sugere que outras espécies de metanotróficas, ainda pouco conhecidas, relacionadas a este filo podem estar presentes no reator. O potencial de oxidação anaeróbia do metano foi determinado para ambas amostras e revelaram que a atividade metanotrófica da biomassa foi aproximadamente três vezes maior que a do inóculo. Em suma, estes resultados sugerem que o inóculo usado e as condições de cultivo aplicadas foram adequados para o enriquecimento de metanotróficas.

Palavras-chave: microrganismos metanotróficos; atividade metanotrófica; reator em bateladas sequenciais; pirosequenciamento; lodo de UASB.

\section{ABSTRACT}

In this study, methanotrophic microorganisms were enriched from sludge derived from a UASB reactor treating domestic sewage. The enrichment was performed in a sequencing batch reactor (RBS) with an autotrophic medium containing nitrite and nitrate. The nitrite and nitrate removal efficiencies were $68 \%$ and $53 \%$, respectively, probably due to heterotrophic denitrification. Archaeal cells of the ANME-I and ANME-II groups were detected by PCR throughout the whole cultivation period. The microbial community composition of the biomass present in the inoculum and enriched in RBS after 100 days of operation was investigated and compared with the help of data obtained from pyrosequencing analyses. Pyrosequencing analysis demonstrated that the community enriched in the reactor had differing composition from the inoculum. The dominant phyla detected in the inoculum were Synergistestes, Firmicutes and Euryarchaeota while in the enriched biomass Planctomycetes, Verrucomicrobia, Chloroflexi and Proteobacteria predominated. The cultivation conditions applied decreased the abundance of Methanobacterium (from 8 to 1\%) and selected for methanotrophic bacteria such as Methylocaldum, Methylocistis and Methylosinus. Sequences of Methylocaldum sp. accounted for $2.5 \%$ of the total reads. The presence and high predominance of Verrucomicrobia in the enriched biomass suggest that other unknown methanotrophic species related to this phylum might also have occurred in the reactor. The potential for anaerobic oxidation of methane was determined for both samples and revealed that the methanotrophic activity of the enriched biomass was almost three times greater than in the inoculum. Taken together these results indicated that the inoculum used and the cultivation conditions applied were adequate for the methanotrophic enrichment.

Keywords: methanotrophic microorganisms; methanotrophic activity; sequencing batch reactor; pyrosequencing; UASB reactor sludge.

'Doutoranda em Saneamento pela Universidade Federal de Minas Gerais (UFMG) - Belo Horizonte (MG), Brasil.

²Estudante de Engenharia Ambiental pela UFMG - Belo Horizonte (MG), Brasil.

${ }^{3}$ Doutor em Engenharia Ambiental pela University of Newcastle Upon Tyne - Newcastle, Inglaterra.

${ }^{4}$ Doutora em Hidráulica e Saneamento pela Universidade de São Paulo (USP) - São Paulo (SP), Brasil.

Endereço para correspondência: Juliana Calábria de Araújo - Avenida Antônio Carlos, 6667 - Pampulha - 31270-901 - Belo Horizonte (MG), Brasil - E-mail: juliana@desa.ufmg.br Recebido: 04/08/14 - Aceito: 05/05/15 - Reg. ABES: 138732 


\section{INTRODUÇÃO}

Atualmente, as emissões significativas do gás metano $\left(\mathrm{CH}_{4}\right)$ vêm sendo relacionadas às fontes antrópicas, como o uso do solo para a pecuária, agricultura e emissão por processos de tratamento e armazenamento de resíduos sólidos e efluentes líquidos, como aterros sanitários e reatores anaeróbios (REEBURGH, 2007; KNITTEL \& BOETIUS, 2009)

Dentre as fontes acima, destaca-se o tratamento anaeróbio de esgoto doméstico através de Reatores Anaeróbios de Fluxo Ascendente e de Manta de Lodo (do inglês, Upflow Anaerobic Sludge Blanket - UASB), que no Brasil, é uma tecnologia bem estabelecida para o tratamento de esgoto doméstico (CHERNICHARO, 2007). A comunidade microbiana presente no reator UASB degrada a matéria orgânica na ausência de oxigênio em produtos como gás carbônico, gás sulfídrico e metano. $\mathrm{Na}$ fase gasosa, o metano pode ser coletado e usado como fonte de energia, mas dissolvido no efluente é difícil para ser recuperado, principalmente sob baixas temperaturas (LUESKEN, 2011). A liberação de metano dissolvido no efluente também pode contribuir para o efeito estufa (CAKIR \& STENSTROM, 2005; BOGNER et al., 2008; LUESKEN, 2011; SOUZA \& CHERNICHARO, 2011).

Recentemente, alguns trabalhos detectaram microrganismos metanotróficos, em amostras de água doce, oceanos, pastagens, arrozais (HANSON \& HANSON, 1996) sob condições aeróbias e sedimentos de lagos de água doce, lodos de digestores, zonas marinhas anóxicas sob condições anaeróbias (ETTWIG et al., 2008; HU et al., 2009; KNITTEL \& BOETIUS, 2009; LUESKEN et al., 2011b).

A oxidação aeróbia do metano é realizada por bactérias metanotróficas da classe $\gamma$-Proteobacteria, família Methylococcaceae (Tipo I) e classe $\alpha$-Proteobacteria, famílias Methylocystaceae e Beijerinckiaceae (Tipo II) (WHITTENBURY \& KRIEG, 1984; BOWMAN; SLY; STACKEBRANDT, 1995; HANSON \& HANSON, 1996; LIEBNER \& WAGNER, 2007). Dentro de $\alpha$-Proteobacteria, o gênero Sphingopyxis sp. MD2, isolado de um cultivo microbiano foi relacionado à remoção simultânea de metano e compostos sulfurosos voláteis ( $\operatorname{como~}_{2} \mathrm{~S}$, methanethiol e dimetil sulfeto) utilizando o oxigênio como aceptor de elétrons para ambos compostos. O metano é oxidado a $\mathrm{CO}_{2}$, ao passo que os compostos sulfurosos são oxidados a sulfato via $\mathrm{H}_{2} \mathrm{~S}$ (LEE; KIM; CHO, 2012). Além do filo Proteobacteria, algumas bactérias acidófilas pertencentes ao filo Verrucomicrobia também foram relatadas por Dunfield et al. (2007) como oxidadoras de metano.

A oxidação anaeróbia do metano (OAM) é um mecanismo que pode ser mediado por arquéias anaeróbias (ANME) subgrupos ANME-1, ANME-2 (relacionadas à Methanomicrobiales e Methanosarcinales) (BOETIUS et al., 2000; ORPHAN et al., 2002) e ANME-3 (relacionada à Methanococcoides spp (KNITTEL\& BOETIUS, 2009) ou ainda por bactérias pertencentes ao filo NC10 (HINRICHS et al., 1999; VALENTINE, 2002; NAUHAUS et al., 2005; ETTWIG et al., 2009). A OAM realizada por ANME é usualmente acoplada à redução do sulfato, que produz quantidades relativamente baixas de energia, ou à redução de nitrato (BARNES \& GOLDBERG, 1976; MEULEPAS et al., 2010; SMEMO \& YAVITT, 2011).

A oxidação realizada por bactérias do filo NC10 é um processo designado como N-DAMO, Nitrite-Dependent Anaerobic Methane Oxidation (ETTWIG et al., 2009). Nessa reação, o metano é parcialmente oxidado resultando em compostos orgânicos como metanol ou acetato, que são subsequentemente usados para desnitrificação produzindo dióxido de carbono $\left(\mathrm{CO}_{2}\right)$ e gás nitrogênio $\left(\mathrm{N}_{2}\right)$ (ETTWIG et al., 2009; LUESKEN, 2011). De acordo com Ettwig (2010), estudos de isótopos estáveis sugeriram que microrganismos relacionados ao filo NC10 poderiam fabricar seu próprio oxigênio molecular retirando-o do óxido nitroso proveniente da redução do nitrito. Sendo assim, o oxigênio produzido seria utilizado para oxidar metano por uma via aeróbia em um ambiente anaeróbio.

Pesquisas anteriores demonstraram o enriquecimento de microrganismos desnitrificantes a partir de sedimentos de valas agrícolas (ETTWIG et al., 2008; ETTWIG et al., 2009). Raghoebarsing et al. (2006), enriqueceu N-DAMO utilizando como inóculo sedimentos de água doce. Hu et al. (2009) também enriqueceu este grupo de microrganismos a partir de um inóculo misto contendo sedimentos de água doce, lodo de digestores e lodo de retorno do sistema de lodos ativados.

No Centro de Pesquisa e Treinamento em Saneamento da Universidade Federal de Migas Gerais (UFMG) (CEPTs/DESA/COPASA), Garcia (2009) detectou bactérias e arquéias metanotróficas na escuma e no lodo, respectivamente, em diferentes reatores UASB tratando esgotos domésticos. Não obstante, a identificação e enriquecimento desses microrganismos não foi realizada, tampouco foram feitos ensaios para comprovar o potencial de oxidação aeróbio e anaeróbio de metano, por parte das amostras investigadas

Diante disso e da escassez de trabalhos a respeito desse grupo de microrganismos em amostras de lodo proveniente exclusivamente de reatores UASB tratando esgoto doméstico, o presente trabalho teve como objetivo enriquecer microrganismos metanotróficos, incluindo metanotróficos relacionados ao processo N-DAMO, em um reator em batelada sequencial (RBS), a partir de lodo anaeróbio proveniente de um reator UASB. Pretendeu-se ainda verificar a atividade metanotrófica do inóculo e da biomassa enriquecida para estabelecer o potencial de oxidação anaeróbia do metano por esses microrganismos.

\section{MATERIAL E MÉTODOS}

\section{Lodo de Inóculo e aparato experimental}

O lodo proveniente de um reator UASB tratando esgotos domésticos de Belo Horizonte foi utilizado como inóculo para enriquecer microrganismos metanotróficos devido a estudos prévios que detectaram 
arquéias metanotróficas por PCR nessas amostras (GARCIA, 2009) com os pares de primers ANME-F e 907R (THOMSEN; FINSTER; RAMSING, 2001) sugerindo, portanto, que eles poderiam estar presentes. Para o enriquecimento desses microrganismos, um fermentador de vidro em escala de bancada de 1,3 L (BioFlo110, New Brunswick Scientific Co.,Enfield, CT, USA) foi utilizado. O equipamento possui controle automático de temperatura (manta aquecedora), eletrodo de $\mathrm{pH}$, agitação, sensor de oxigênio dissolvido (OD) e sensores de nível para controlar o afluente e efluente do interior do RBS.

A temperatura foi mantida a $35^{\circ} \mathrm{C}$ (HU et al., 2009) e o $\mathrm{pH}$ permaneceu no intervalo de 6,8 a 7,5 (LUESKEN, 2011). As condições de anaerobiose foram mantidas injetando-se gás $\mathrm{N}_{2}$ (99.99\%) no meio líquido e na atmosfera livre do frasco de alimentação. Na atmosfera do reator, fluxionava-se diariamente gás metano (99,9\%) a uma vazão de 100 mL.min ${ }^{-1}$ durante 3 minutos.

O reator foi alimentado com o meio autotrófico com composição similar à previamente descrita por Luesken et al. (2011a). A concentração final de nitrito e nitrato no meio foram $100 \mathrm{mg} \cdot \mathrm{L}^{-1}$ e $25 \mathrm{mg} \cdot \mathrm{L}^{-1}$, respectivamente. $1 \mathrm{~L}$ de lodo de UASB foi utilizado como inóculo a uma concentração de 16 g.L-1 de STV.

O fermentador foi monitorado durante um período de 241 dias sob a forma de RBS e tempo de detenção hidráulica (TDH) de 47 horas, compreendendo dois ciclos de operação de 23,5 horas cada, que incluíram três fases:

1. fase de alimentação (3 horas), na qual $500 \mathrm{~mL}$ de meio de cultura eram adicionados ao reator (sob contínua agitação) e permaneciam reagindo com a biomassa por cerca de 20 horas;

2. fase de sedimentação da biomassa (30 minutos), na qual a agitação era desligada permitindo a decantação da biomassa;

3. fase de retirada do meio (30 minutos), na qual $500 \mathrm{~mL}$ de efluente eram retirados.

\section{Procedimentos analíticos}

As concentrações de nitrito e nitrato afluentes e efluentes foram monitoradas três vezes por semana. A concentração de $\mathrm{NO}_{2}-\mathrm{N}$ foi determinada colorimetricamente, de acordo com o método $4500 \mathrm{NO}_{2}-\mathrm{B}$ (APHA, 2005). Através do método, obteve-se nitrogênio na forma de nitrito $\left(\mathrm{N}^{-\mathrm{NO}_{2}}{ }^{-}\right)$que foi convertido à concentração de $\mathrm{NO}_{2}^{-}$para análises gráficas dos resultados. Sólidos totais voláteis também foram determinados de acordo com APHA (2005).

A concentração de nitrato foi analisada via cromatógrafo iônico (Metrohm, Herisau, Switzerland) com supressão química e detector de condutividade, através do método 4110B (APHA, 2005).

Análises estatísticas utilizando-se o programa Statistica 8.0 foram realizadas para comparar a eficiência de remoção de nitrito e nitrato ao longo dos diferentes períodos de operação do RBS. Para esta análise, utilizou-se o teste de Kruskall-Wallis ( $\alpha=5 \%)$. Comparações entre as concentrações afluentes e efluentes de nitrito e nitrato em cada período também foram avaliadas através do teste de Mann-Whitney $(\alpha=5 \%)$

\section{Análise da comunidade microbiana presente no inóculo e na biomassa do reator em batelada sequencial}

\section{Detecção através de $P C R$}

A biomassa do RBS foi amostrada nos dias 0 (inóculo), 100 e 191 dias de operação. O RBS foi subdividido em 3 períodos operacionais, classificados como período 1 (dias 1 a 100), período 2 (dias 101 a 191), período 3 (dias 192 a 241). Ressalta-se, portanto, que a subdivisão em períodos foi determinada em função das coletas de biomassa para os ensaios de oxidação do metano e análises moleculares.

Para análises moleculares, $10 \mathrm{~mL}$ das amostras do inóculo e da biomassa do reator foram coletadas, centrifugadas a $14.000 \mathrm{rpm}$ por 10 minutos e o pellet foi usado para os estudos. O DNA foi extraído usando o protocolo descrito por EGLI et al. (2003). As concentrações de DNA total foram estimadas através de um espectrofotômetro NanoDrop (Nanodrop Technologies, Wilmington, DE, USA). A partir do DNA obtido, fragmentos da subunidade 16S do gene do RNA ribossomal foram amplificados utilizando-se iniciadores específicos para microrganismos metanotróficos. Para detectar arquéias metanotróficas utilizaram-se os primers ANME-F e 907R (THOMSEN; FINSTER; RAMSING, 2001).

Para a detecção de metanotróficas desnitrificantes, foi realizada uma PCR direta com os iniciadores A189_b (LUESKEN et al., 2011b) e o 682R (HOLMES et al., 1995), de acordo com metodologia descrita por Ettwig et al. (2009). Para a detecção de Candidatus Methylomirabilis oxyfera (bactéria pertencente ao filo NC10), foi realizada uma PCR nested com os iniciadores A189_b e cmo682 (LUESKEN et al., 2011b). O produto desta reação foi utilizado em um segundo PCR com os iniciadores cmo182 e cmo568 (LUESKEN et al., 2011b). A presença e o tamanho dos fragmentos amplificados foram visualizados em gel de agarose $1 \%$, através da aplicação de uma alíquota de $2 \mu \mathrm{L}$ do produto da PCR.

\section{Pirosequenciamento 454}

A técnica do pirosequenciamento foi utilizada para análise da comunidade microbiana das amostras do inóculo e 100 dias de operação do RBS. O DNA genômico foi extraído de acordo com Egli et al. (2003) e purificado usando-se o kit de purificação Wizard ${ }^{\circledR}$ Genomic DNA Purification Kit (Promega, Madison, WI, USA). O DNA total foi estimado utilizando o Espectrofotômetro NanoDrop (NanoDrop Technologies ${ }^{\bullet}$, Wilmington, DE, USA).

$\mathrm{O}$ DNA foi precipitado em etanol $95 \%$ e seco à $50^{\circ} \mathrm{C}$. As amostras desidratadas foram enviadas para o Instituto de Agrobiotecnologia de Rosario (INDEAR, Santa Fe, Argentina) onde o pirosequenciamento foi 
realizado usando um equipamento 454 GS-FLX (Life Sciences, Roche). Barcodes com $10 \mathrm{pb}$ foram incluídos para cada amostra. Os genes RNAr 16S foram amplificados com primers para a região v4: 515F (5'CACGACGTTGTAAAACGACGTGCCAGCMGCCGCGGTAA-3'), no qual uma sequência adaptadora (tag) foi incluído e 806R (5'-CAGGAAACAGCTATGACCGGACTACVSGGGTATCTAAT- 3'). As sequências foram analisadas utilizando-se o software Quantitative Insights Into Microbial Ecology (QIIME) (CAPORASO et al., 2010). Todas as sequências obtidas foram depositadas na base de dados Sequence Read Archive (SRA) do National Center for Biotechnology Information (NCBI) sob o número de acesso SRP049924. As sequências com comprimento inferior a $200 \mathrm{pb}$, coeficiente de qualidade menor que 25, homopolímeros de tamanho maior que 6 e bases ambíguas foram removidas. Para a definição das unidades taxonômicas operacionais (UTO), utilizou-se o algoritmo UCLUST (EDGAR, 2010) adotando-se similaridades de $97 \%$. As sequências foram classificadas usando-se a ferramenta Ribomossal Database Project (http://rdp.cme. msu.edu/classifier/classifier.jsp).

Os índices de diversidade alfa Shannon-Wiener $\left(H^{\prime}\right)$, Equitabilidade de Pielou (J') e diversidade beta (Bray-Curtis) de cada amostra foram calculados através do software Past (versão 3.0). As UTOs classificadas como diferentes gêneros de metanotróficas foram selecionadas e usadas para a construção de uma árvore filogenética por meio do software MEGA 4 (TAMURA et al., 2007) por meio do método neighbor-joining. Realizou-se o teste de Bootstrap para 1000 recombinações para realizar uma estimativa de confiança da árvore.

\section{Ensaio do Potencial de Oxidação Anaeróbia do Metano e determinação da atividade metanotrófica}

Para a realização dos ensaios, utilizou-se o Procedimento Operacional Padrão da Rede PROSAB Microbiologia (GARCIA, 2009) modificado de Mcdonald et al. (1999). A atividade metanotrófica inicial e no dia 191 foram realizadas com lodo de inóculo do reator UASB e lodo coletado do RBS após 191 dias de operação, respectivamente.

Cerca de $20 \mathrm{~mL}$ de lodo e/ou biomassa do reator foram previamente lavadas com tampão fosfato salino (PBS 1X: $130 \mathrm{mM} \mathrm{NaCl}$; $\left.10 \mathrm{mM} \mathrm{Na}_{2} \mathrm{HPO}_{4} 12 \mathrm{H}_{2} \mathrm{O}, 3 \mathrm{mM} \mathrm{NaH} \mathrm{PO}_{4} \cdot \mathrm{H}_{2} \mathrm{O} ; \mathrm{pH} 7,2\right)$ centrifugados por 10 minutos a $4.000 \mathrm{rpm}$. O pellet foi ressuspendido em $20 \mathrm{~mL}$ de meio de cultura (LUESKEN et al., 2011a), homogeneizado e as alíquotas distribuídas em frascos de antibiótico de $110 \mathrm{~mL}$ previamente autoclavados. Após a distribuição, os frascos foram vedados com batoques de borracha (butila) e lacres de alumínio. Posterimente, para o estabelecimento de condições anaeróbias no interior dos frascos, a atmosfera de cada frasco foi "lavada" com gás inerte $\left(\mathrm{N}_{2}, 99,99 \%\right)$, através da introdução de uma agulha de entrada de gás e outra de saída no meio do batoque de borracha, durante 2 minutos.
$\mathrm{Na}$ atmosfera vazia de cada frasco, adicionou-se $20 \mathrm{~mL}$ de metano $(99,9 \%)$ por meio de uma seringa esmerilhada. Entretanto, no caso dos frascos contendo lodo de inóculo (oriundo de reator UASB) como este apresentava produção de metano, a adição do gás metano bem como a determinação do consumo deste composto, só foram realizadas após a diminuição da atividade metanogênica. Esse declínio do volume de metano no headspace dos frascos foi monitorado duas vezes por semana através das coletas de biogás e análises cromatográficas.

Para a o lodo de inóculo (UASB), os ensaios foram realizados em triplicata utilizando-se uma triplicata de lodo autoclavado como controle. Para os ensaios com a biomassa enriquecida, realizou-se os ensaios em duplicata, uma vez que a retirada excessiva de biomassa do reator poderia prejudicar o experimento de enriquecimento. As amostras foram incubadas em agitador orbital a $250 \mathrm{rpm}$ a uma temperatura de $30^{\circ} \mathrm{C}$.

Realizou-se amostragem de $1 \mathrm{~mL}$ de gás contido no headspace duas vezes por semana a fim de verificar a queda da porcentagem de metano nos ensaios. O gás coletado foi injetado em cromatógrafo gasoso (Perkin Helmer Auto System equipado com detector de condutividade térmica TCD). As análises cromatográficas ocorreram utilizando-se o gás $\mathrm{He}$ como gás de arraste e temperatura da coluna em $220^{\circ} \mathrm{C}$. Cada corrida teve o tempo de duração total de 4,5 minutos, sendo que o tempo de retenção do metano ocorreu por volta de 2,75 min.

O volume de metano foi calculado a partir da porcentagem de metano encontrada, pelo volume do headspace do frasco. $\mathrm{O}$ valor resultante foi dividido por 100, para obter-se o volume de metano contido nas amostras. A porcentagem de metano foi obtida utilizando-se o gás padrão (47,1\% de $\mathrm{CH}_{4}, 25 \%$ de $\mathrm{CO}_{2}, 2 \%$ de $\mathrm{H}_{2}, 5 \% \mathrm{CO}$ e $\left.20,9 \% \mathrm{~N}_{2}\right)$ de composição e área conhecidas.

Gráficos de séries temporais foram plotados e, as taxas de consumo de metano foram calculadas a partir da derivada do volume em função do tempo (dV/dt) nos pontos correspondente aos dias analisados. Como resultados, utilizou-se o valor da mediana das taxas. $\mathrm{O}$ valor da mediana das taxas calculado foi dividido pela massa de lodo inoculada (g.STV) pra obtenção da atividade metanotrófica dos ensaios.

\section{RESULTADOS E DISCUSSÃO}

\section{Enriquecimento em reator em batelada sequencial}

A Figura 1 apresenta as concentrações de nitrito e nitrato (afluentes e efluentes) e eficiência de remoção ao longo dos 241 dias de operação do reator, divididos em 3 períodos (P1, P2 e P3). O periodo 1 (P1), teve duração de 100 dias, e correspondeu à fase inicial de operação do reator. Esta foi marcada, inicialmente, pelo consumo intenso de nitrito, o qual, por volta do $50^{\circ}$ dia, diminuiu. Para o nitrato, o consumo mais intenso ocorreu nos 100 primeiros dias. 
Durante P1, possivelmente a desnitrificação heterotrófica foi o processo predominante. A atmosfera anaeróbia e a presença de nitrito e nitrato permitiram a estabilização da matéria orgânica oriunda do inóculo e da própria biomassa. Após o consumo da matéria orgânica prontamente disponível, teve início o processo de respiração endógena das bactérias heterotróficas desnitrificantes, uma vez que o meio de cultura era autotrófico e não poderia garantir suplementação necessária a estas bactérias.

O período 2 (P2) caracterizou-se pela continuidade no decaimento do consumo de nitrato e nitrito e durou aproximadamente 90 dias. Nessa etapa, exauriu-se qualquer fonte externa de substratos orgânicos, o que resultou em significativa redução da atividade desnitrificante. As concentrações de nitrito e nitrato efluente oscilaram, em alguns momentos foram altas (próximas às concentrações afluentes), e, em outros, baixas, não sendo possível estabelecer uma tendência nítida de consumo. Não obstante, foi observada diferença significativa entre as concentrações afluentes e efluentes de nitrito e nitrato durante o período (Mann-Whitney, $\mathrm{p}=0$ para nitrito e nitrato; $\alpha=5 \%$ ), indicando que ambos aceptores foram consumidos.
O período 3 (P3) foi marcado por uma redução ainda mais elevada no consumo de nitrito e nitrato (Mann-Whitney, $\mathrm{p}=0$ para nitrito; $\mathrm{e}$ $\mathrm{p}=0,00001$ para nitrato; $\alpha=5 \%)$.

Os resultados de eficiência de remoção de nitrito e nitrato no interior do reator para todo o período avaliado apresentaram média para nitrito de $68 \%$ ( $\pm 24 \%)$ (mediana=70\%) e média para nitrato de $53 \%$ $( \pm 22 \%)$ (mediana $=53 \%)$. Para verificar a existência de diferenças significativas para a eficiência de remoção de nitrito e nitrato entre os períodos amostrados ( $\mathrm{P} 1$ a $\mathrm{P} 3)$, a análise de variância não paramétrica Kruskall Wallis foi utilizada $(\alpha=5 \%)$.

A eficiência de remoção de nitrito no período P1 apresentou diferença significativa em relação aos demais períodos (valor de $\mathrm{p}=0,0020$ e 0,0001, respectivamente, para P2 e P3). Os períodos P2 e P3, entretanto, não apresentaram diferenças significativas quando comparados entre si $(\mathrm{p}=0.6721)$. Ao que tudo indica, o período $\mathrm{P} 2$ parece ser um período de transição entre as fases 2 e 3, e tal fato poderia justificar a ausência de diferença estatística entre estes períodos.

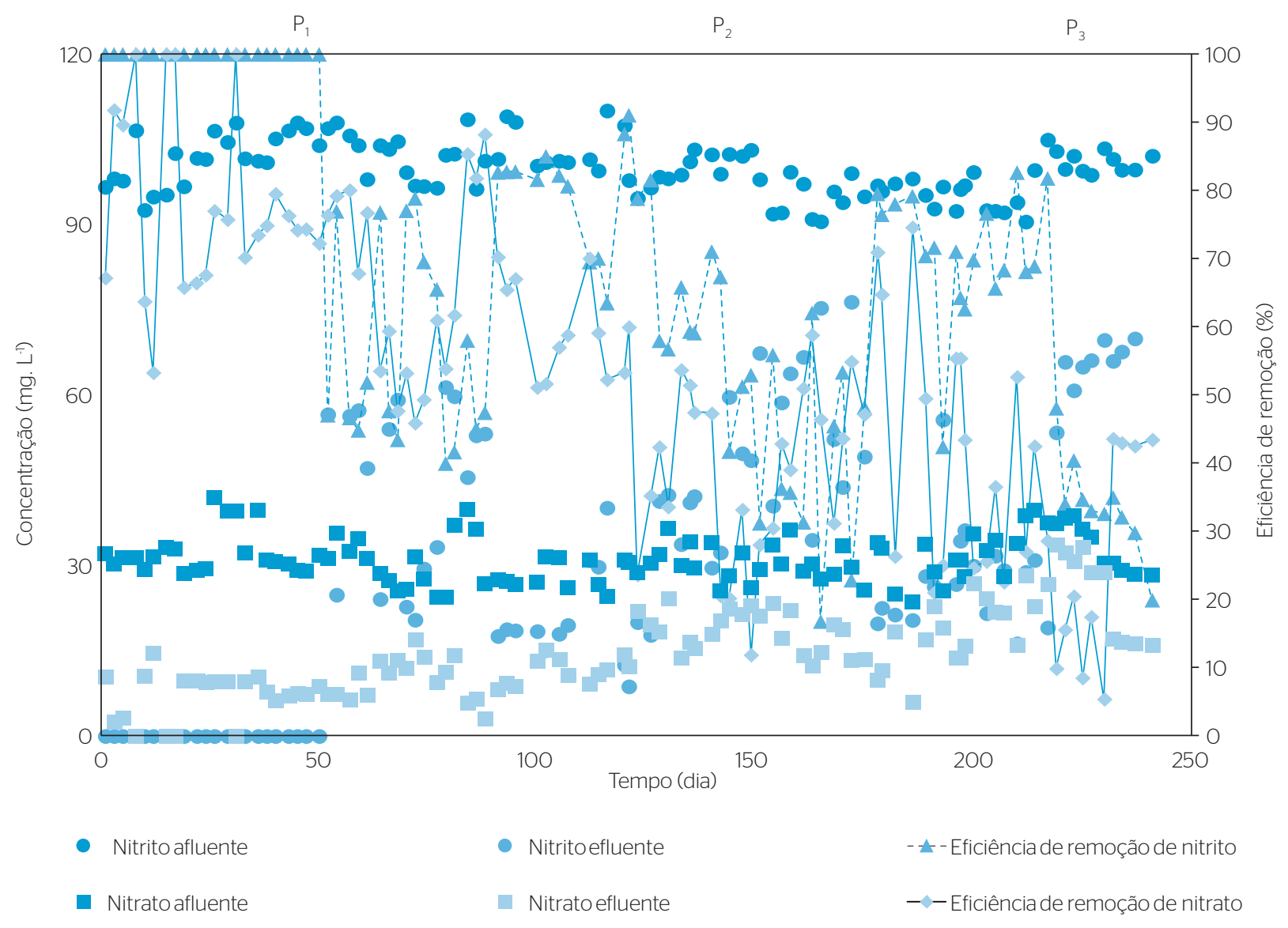

Figura 1 - Concentração de Nitrito e Nitrato afluente e efluente e eficiência de remoção durante a operação do reator em batelada sequencial (subdividido nos períodos $\mathrm{P} 1, \mathrm{P} 2$ e P3). 
Para os dados de nitrato, observou-se a mesma tendência, anteriormente apresentada para nitrito, apontando diferença significativa de $\mathrm{P} 1$ com os demais períodos ( $\mathrm{p}=0$ para $\mathrm{P} 2$ e P3). De acordo com a análise estatística, não houve diferença entre os períodos 2 e 3 ( $p=0,1176)$.

Para melhor compreensão dos dados, gráficos do tipo Box-plot foram construídos com dados referentes às eficiências de remoção de nitrito e nitrato ao longo dos períodos. A Figura 2 apresenta os dados obtidos.

A partir das análises gráficas bem como das análises estatísticas pode-se verificar que o período 1 e 3 apresentaram, respectivamente, o maior e menor consumo para ambos os aceptores de elétrons. A presença de arquéias metanotróficas no interior do reator poderia justificar o consumo do nitrato, que, assim como reportado na literatura (ETTWIG et al., 2009; HU et al., 2009) é preferencialmente consumido pelas arquéias na oxidação do metano. O nitrito disponível é consumido pelas bactérias metanotróficas desnitrificantes (filo NC10) (ETTWIG et al., 2009). Entretanto, dados preliminares de detecção via PCR não detectaram bactérias do filo NC10 nas amostras da biomassa do RBS.

Nesse sentido, o consumo simultâneo de nitrito e nitrato pode indicar o crescimento de grupos microbianos distintos que serão discutidos no próximo item.

\section{Análise da comunidade microbiana do inóculo e enriquecida no reator}

\section{Detecção por PCR com primers específicos para metanotróficas}

Arquéias metanotróficas do grupo ANME foram detectadas através da PCR com iniciadores específicos (ANME-F/ 907R), nas amostras do inóculo bem como na biomassa do reator nos períodos P1 (1-100) e P2 (101-191) conforme apresentado na Figura 3.

Os microrganismos do grupo ANME pertencem ao filo Euryarchaeota e estão relacionados às arquéias metanogênicas, que, dentro de alguns grupos, são capazes de realizar a metanogênese reversa. De acordo

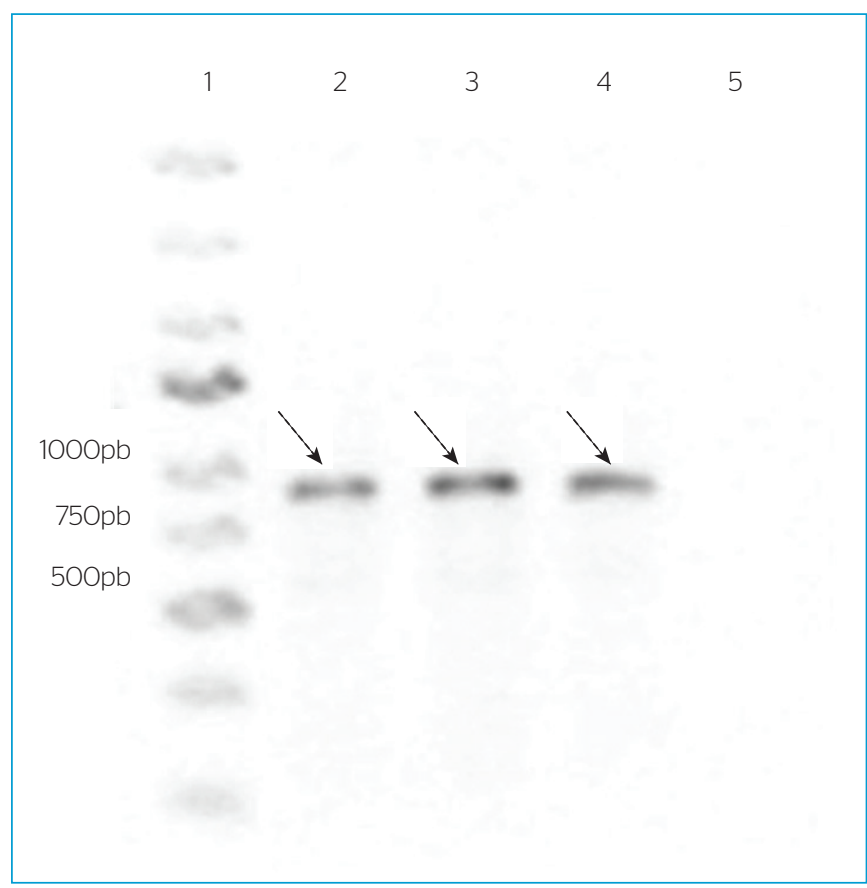

Figura 3 - Detecção por PCR com os primers ANME-F e 907R para o RNAr $16 \mathrm{~S}$ de arquéias metanotróficas. (1) Padrão de peso molecular (Ladder Express); (2) inóculo; (3) biomassa do RBS durante o período P1; (4) biomassa do reator em batelada sequencial durante o período P2; (5) controle negativo.
(A)

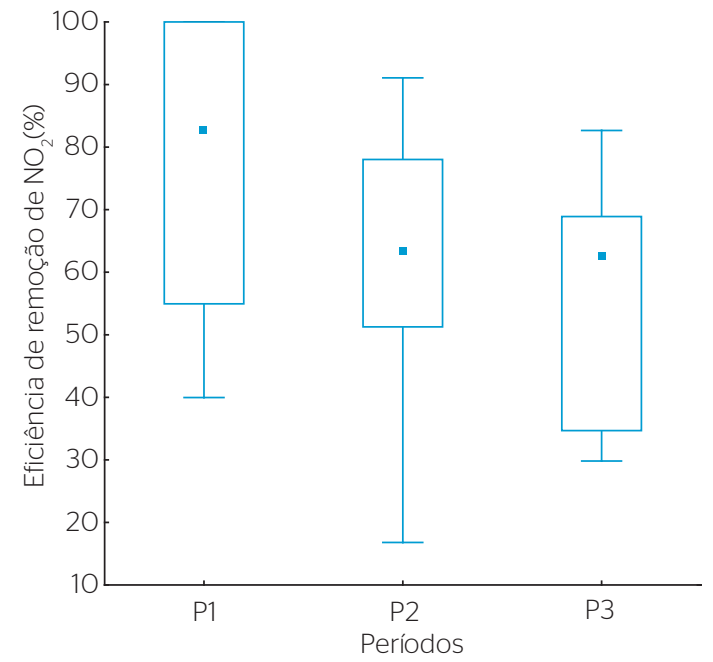

(B)

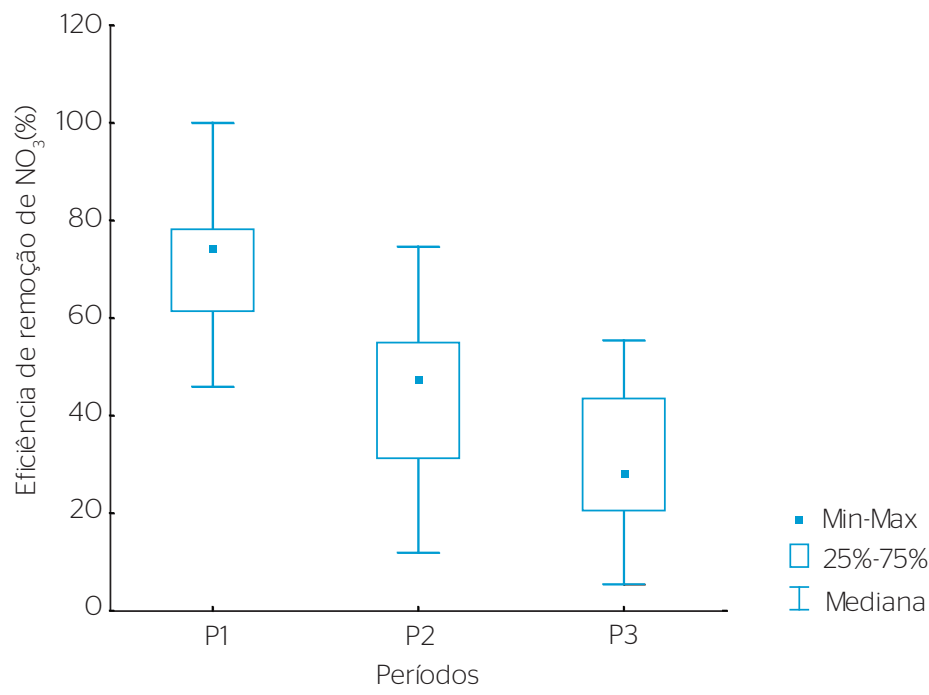

Figura 2 - Box-plot da remoção de eficiência de nitrito (A) e nitrato (B) nos períodos de operação do reator em batelada sequencial (P1 a P3). 
com estudos do gene RNAr 16S, os grupos ANME -1, ANME-2 e ANME-3 não são monofiléticos e a distância filogenética entre estes é grande podendo apresentar uma similaridade que varia entre $75 \mathrm{e}$ 92\% (KNITTEL \& BOETIUS, 2009). Orphan et al. (2002) mostraram que as células de ANME-I e ANME-II assimilam o carbono do metano durante a OAM. Além da identificação através do gene RNAr 16S, as populações de ANME têm sido identificadas pelo uso de biomarcadores específicos lipídicos e pelo uso de isótopos de carbono estáveis (KNITTEL \& BOETIUS, 2009).

Metanotróficas desnitrificantes pertencentes ao filo NC10, tal como o gênero Candidatus Methylomirabilis oxyfera, não foram detectadas por PCR usando os primers descritos por Ettwig et al. (2009).

\section{Composição da comunidade microbiana por pirosequenciamento 454}

O pirosequenciamento das amostras do inóculo e da biomassa enriquecida após 100 dias de operação do reator (P1), gerou 4.843 e 8.838 sequências de alta qualidade, respectivamente, totalizando 13.681 sequências recuperadas. A maioria das sequências possuía entre 200 a 220 pb e foram agrupadas em 407 unidades taxonômicas operacionais (UTO). Entre o total de UTOs analisadas, apenas 2,7\% foram comuns às duas amostras.

A composição da comunidade microbiana em nível de filo, para as duas amostras analisadas, é apresentada na Figura 4. Os filos mais abundantes, em ambas as amostras foram Synergistetes $(53 \pm 37 \%)$,

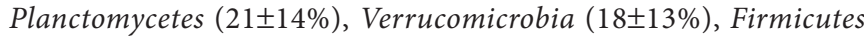

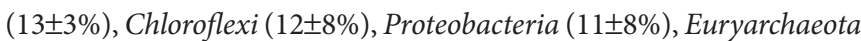

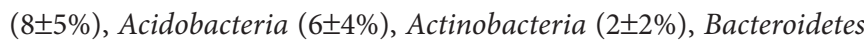

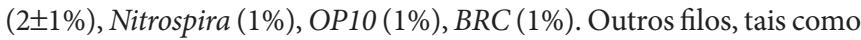
Gemmatimonadetes, Spirochaetes e WS3 estiveram presentes em baixa abundância $(\leq 0,2 \%)$. Para as amostras do inóculo, os filos mais abundantes foram Synergistetes (53\%), Firmicutes (13\%) e Euryarchaetoa (8\%), ao passo que, para a amostra enriquecida após 100 dias de cultivo, predominaram os filos Planctomycetes (21\%), seguidos do Verrucomicrobia (18\%) e Chloroflexi (12\%).

As duas amostras analisadas apresentaram diferenças na comunidade microbiana quando o índice de similaridade de Bray Curtis foi calculado. $\mathrm{O}$ índice apresentou valor baixo $(0,01)$ evidenciando baixa similaridade entre as amostras, indicando que as comunidades são bem diferentes em relação à composição e abundância das UTOs. Portanto, sugere-se que o meio de cultura utilizado, bem como as condições operacionais do reator, exerceram forte pressão seletiva modificando a comunidade microbiana ao longo dos 100 dias de cultivo, inibindo o crescimento de Synergistetes, diminuindo sua pressão competitiva, e com isto, o crescimento das outras espécies menos competidoras foi favorecido, aumentando assim suas abundâncias e equitabilidade da comunidade. O grupo Firmicutes também teve sua abundância reduzida no

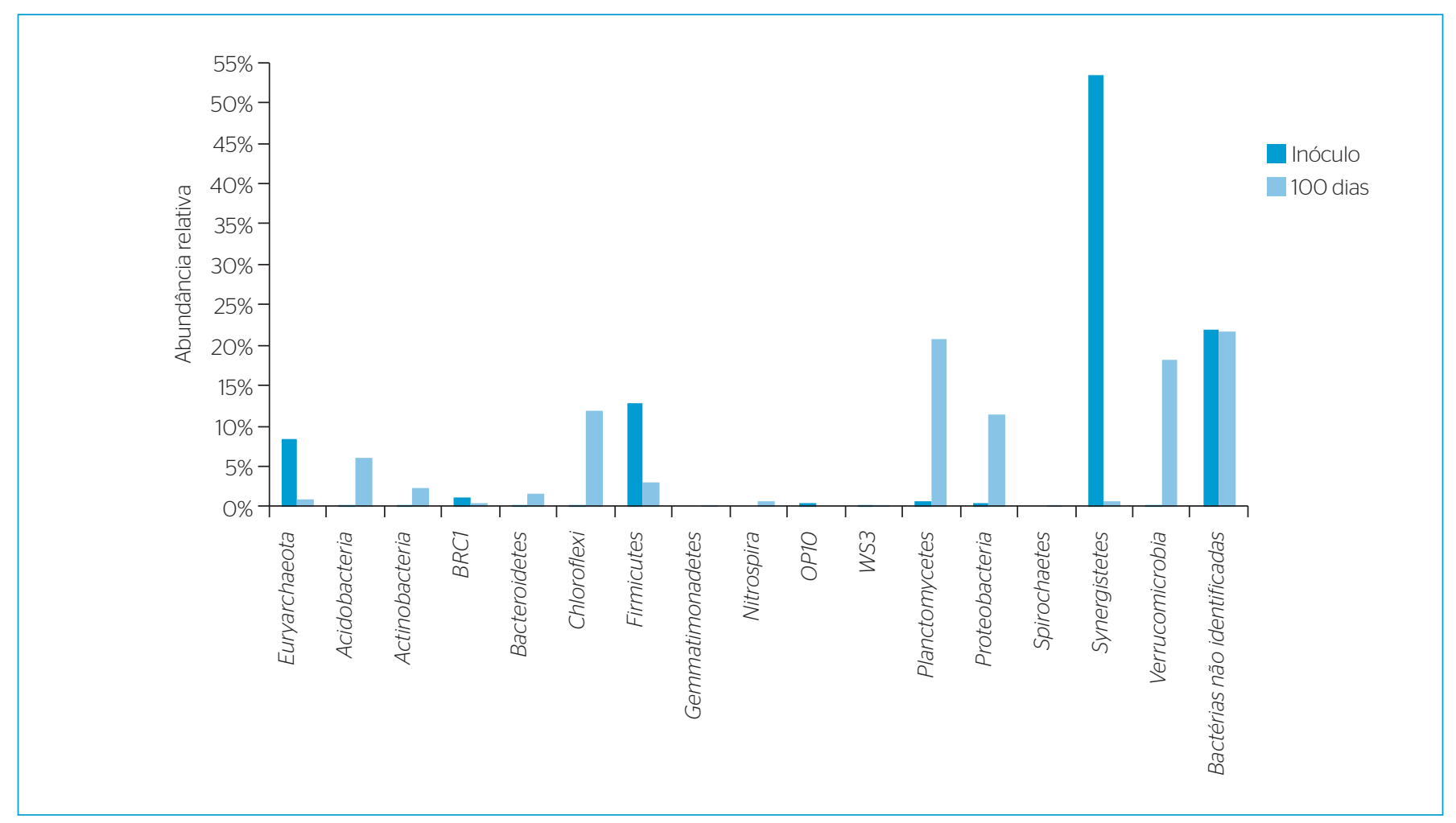

Figura 4 - Composição da Comunidade Microbiana presente no inóculo e do reator em batelada sequencial (100 dias de operação) em nível de filo. A abundância relativa é apresentada como a porcentagem dos diferentes filos em relação ao número total de filos presentes nas amostras. 
reator ao longo do cultivo (Figura 4), indicando que as condições do reator (meio autotrófico) não eram favoráveis para o desenvolvimento destas bactérias que em sua maioria são fermentadoras e geralmente estão presentes em sistemas anaeróbios com alta concentração de matéria orgânica.

Os índices de Shannon $\left(H^{\prime}\right)$ e Equitabilidade de Pielou $\left(J^{\prime}\right)$ foram analisados e também mostraram que houve diferença entre as comunidades presentes no inóculo e após 100 dias de operação do reator (Tabela 1). Para o índice de Shannon, os resultados indicaram grande diversidade entre as duas comunidades microbianas analisadas. Dessa forma, o índice de Equitabilidade $\left(J^{\prime}\right)$ apresentou valores inferiores a 1, sugerindo heterogeneidade de espécies para ambas amostras. Não obstante, um pequeno aumento entre as amostras do inóculo e biomassa do reator foram observadas podendo indicar uma tendência à uniformidade da comunidade ao longo do período de cultivo e operação do reator.

\section{Comparação dos grupos taxonômicos mais abundantes}

Para a construção dos gráficos dos táxons mais abundantes, considerou-se as ordens e os gêneros presentes em abundância relativa igual ou acima de 1\% (WANG et al., 2012). Do total de 407 UTOs obtidas a partir do pirosequenciamento, $62,16 \%$ foram classificadas em nível de ordem e $36,1 \%$ foram classificadas em nível de gênero. A Figura 5, apresentam, respectivamente, as ordens e os gêneros iguais ou acima de $1 \%$ presentes nas amostras.

\section{Microrganismos predominantes no lodo do inóculo}

No lodo de UASB utilizado como inóculo do RBS, foram predominantes os gêneros da ordem Synergistales (Synergistetes): Aminobacterium (18\%), Aminomonas (23\%), Synergistes (6\%) e Cloacibacillus (1\%) (Figura 5). Esses microrganismos são anaeróbios estritos, fermentadores de aminoácidos e foram relatadas em trabalhos anteriores em sistemas de tratamento de esgotos (GANESAN et al., 2008; MAC CONELL, 2014). Esses microrganismos disponibilizam ácidos graxos de cadeia curta para as arquéias metanogênicas, presentes em elevada abundância (8\%) nesse sistema (SILVA, 2012; COSTA et al., 2014). Bactérias pertencentes à ordem Clostridiales também foram

Tabela 1 - Análise da diversidade das amostras do inóculo e reator em batelada sequencial (100 dias de operação) por meio de índices de Shannon e Equitabilidade.

\begin{tabular}{l|c|c} 
& Inóculo & RBS -100 dias \\
\hline Número de Sequências lidas & 4.843 & 8.838 \\
\hline Riqueza & 201 UTOs & 221 UTOs \\
\hline Shannon $\left(H^{\prime}\right)$ & $3,11( \pm 0,3)$ & $3,51( \pm 0,3)$ \\
\hline Equitabilidade de Pielou $\left(J^{\prime}\right)$ & $0,58( \pm 0,04)$ & $0,65( \pm 0,04)$
\end{tabular}

RBS: reator em batelada sequencial; UTO: unidades taxonômicas operacionais. encontradas no inóculo e depois tiveram sua abundância relativa reduzida ao longo do enriquecimento e cultivo. Essas bactérias são fermentadoras e geralmente encontradas em sistemas anaeróbios (CARDINALI-REZENDE et al., 2013).

Outro gênero predominante no inóculo foi o Methanobacterium (8\%), pertencente ao filo Euryarchaeota. Os microrganismos do gênero Methanobacterium são arquéias metanogênicas hidrogenotróficas (LECLERC et al., 2001; 2004). Leclerc, Delgènes e Godon (2004) também detectaram em um digestor anaeróbio, a dominância de Methanobacterium. Segundo o autor, o gênero supracitado, juntamente com Methanobrevibacter, Methanospirilum, Methanoculleus e Methanocorpusculum são os gêneros de hidrogenotróficas mais frequentemente isolados em reatores anaeróbios. Methanobrevibacter, e Methanospirilum estiveram presentes no lodo de inóculo, porém em baixa abundância (inferior a $0,2 \%$ ). O gênero Methanosaeta, formado por bactérias acetoclásticas, também foi detectado no inóculo em baixa abundância (cerca de 0,2\%). Raskin et al. (1994) utilizando sondas de oligonucleotídeos complementares ao RNAr 16S, identificou em amostras de digestores anaeróbios de lodo de esgoto, os gêneros Methanosarcina e Methanosaeta como os mais abundantes na amostra.

Além dos gêneros relatados, verificou-se a presença da família Veillonellaceae, filo Firmicutes, em 5\% de abundância no inóculo. Cardinali-Rezende et al. (2013) relataram a predominância deste filo em amostras de lodo de reator UASB. O pirosequenciamento não permitiu a classificação destas sequências em nível de gênero. Membros da família Veillonellaceae são gram-positivos, quimiorganotróficos, anaeróbios e morfologicamente diversos, apresentando formas de bacilos, cocos e vibriões (VOS et al., 2009).

Sequências de bactérias do filo BRC1 (1\%) e OP10 (0,5\%) foram detectadas. O filo BRC1 foi descrito na literatura sendo representativo de arrozais, mas além destes ambientes, já foram detectados em sedimentos anóxicos marinhos (DONACHIE; HOU; LEE, 2004) e em reator Anammox (PEREIRA et al., 2014). Tessaro (2012) através de um experimento de DNA-SIP ${ }^{13} \mathrm{CH} 4$, identificou, além de microrganismos metanotróficos (gênero Methylocaldum), microrganismos do filo OP10, o qual o metano marcado havia sido incorporado. Este fato sugere a importância desse filo junto à oxidação do metano, embora seu papel permaneça desconhecido na literatura.

Bactérias redutoras de sulfato relacionadas à OAM em ambientes marinhos, tais como Desufosarcina, Desulfococcus e Desulfobulbus não foram detectadas no inóculo, tampouco após 100 dias de cultivo. Entretanto, outros gêneros de redutoras de sulfato, tais como Desufobacter, Desulfovibrio e Desulfohabdus foram encontradas, sendo os dois primeiros gêneros no inóculo e o último presente na amostra após 100 dias de enriquecimento. 


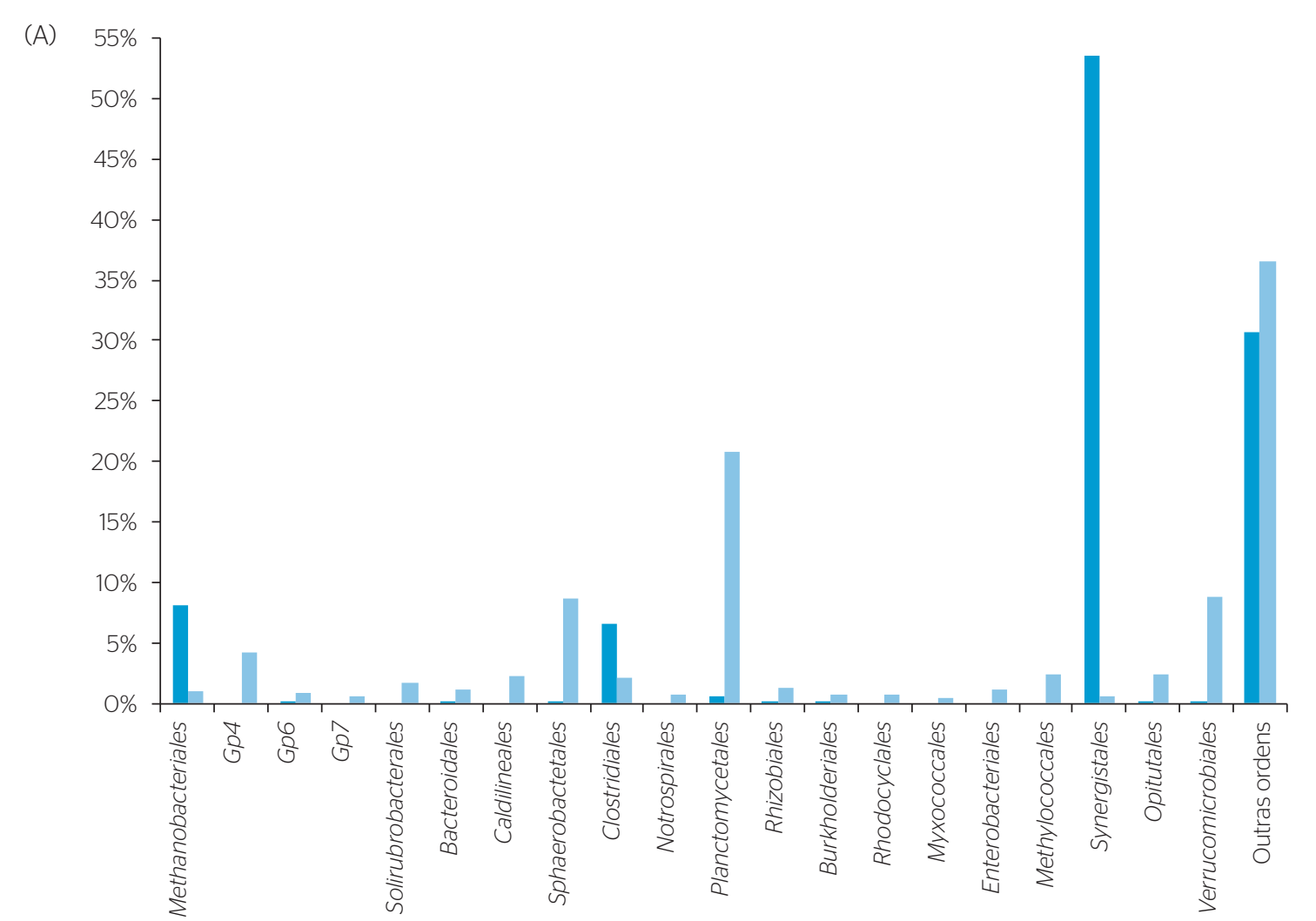

- Inóculo

100 dias

(B)

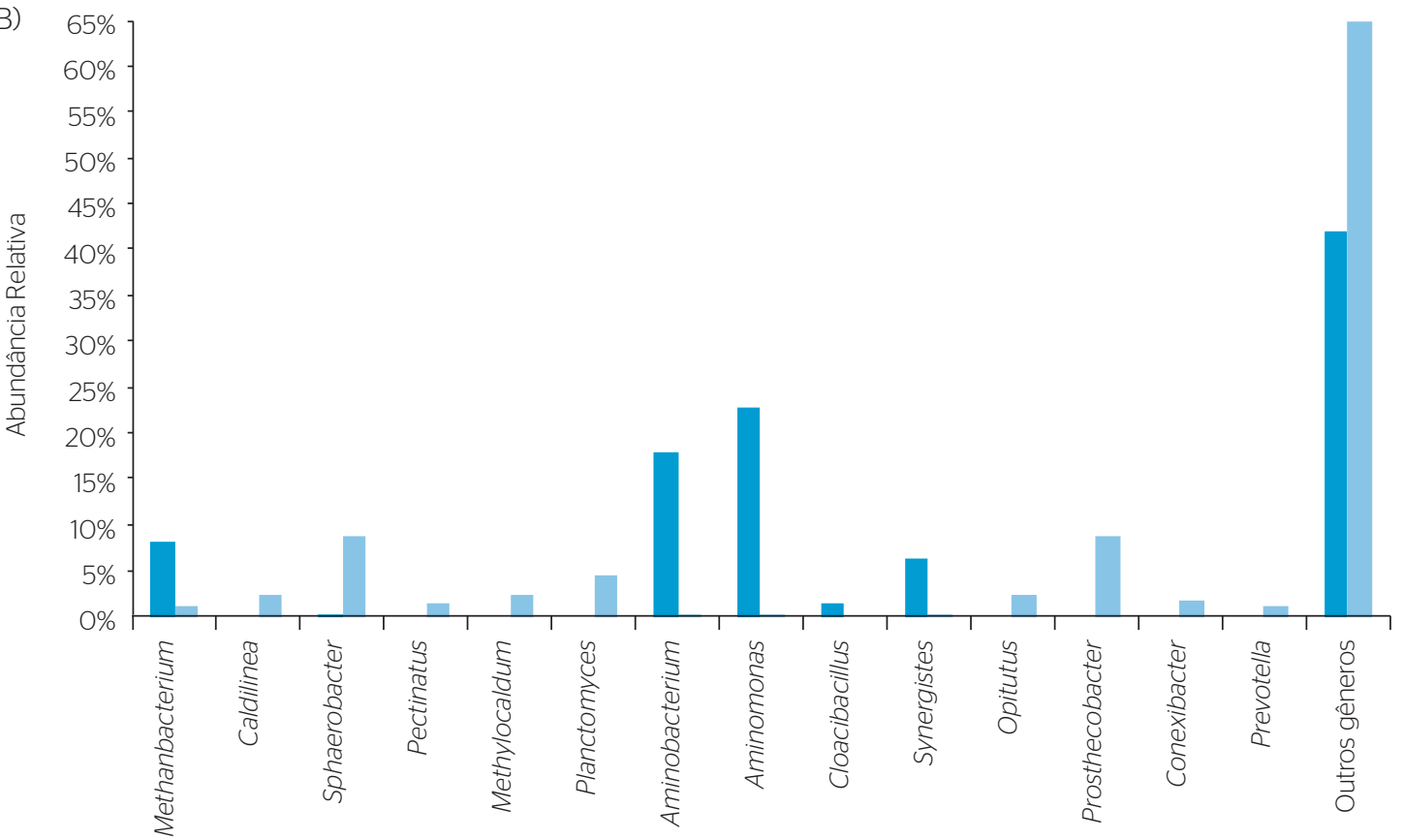

Inóculo

100 dias

Figura 5 - Composição da comunidade microbiana presente no inóculo e após 100 dias de operação. (A) Nível taxonômico de ordem; (B) Nível taxonômico de gênero. As unidades taxonômicas operacionais com abundância relativa inferior a 1\% estão representadas como outros (ordens ou gêneros). 


\section{Gêneros predominantes no reator após 100 dias de enriquecimento e cultivo}

Grande diversidade de níveis taxonômicos foi encontrada na biomassa do reator após 100 dias de cultivo (fase P1). Os microrganismos presentes em maior abundância, envolvidos na oxidação do metano e consumo de nitrato e nitrito serão descritos.

\section{Planctomycetes}

Este filo foi detectado em maior abundância (21\%) (Figura 4). Bactérias pertencentes ao filo Planctomycetes possuem grande número de características distintas e não usuais, como parede celular sem peptideoglicano, compartimentalização interna, além de características moleculares únicas em seus genes RNAr. São aeróbias facultativas, quimiorganotróficas com exceção dos microrganismos responsáveis pela oxidação anaeróbia da amônia (anammox), gram-negativas (em sua maioria) e de crescimento lento. Algumas espécies pertencentes ao gênero Planctomyces são capazes de crescer em meio anaeróbio e reduzir nitrato a nitrito. Além disso, já foram relatadas em sistemas de tratamento de efluentes e lixiviados de aterros sanitários (KRIEG et al., 2010).

Dentro deste filo, predominou a família Planctomycetaceae (16\%), composta por microrganismos aeróbios, comumente descritos em águas oligotróficas, eutróficas e também no solo (KRIEG et al., 2010). O gênero Planctomyces esteve presente em abundância relativa de 5\%. Membros desse gênero crescem em temperatura a $35^{\circ} \mathrm{C}$, temperatura de operação do reator, são aeróbios ou anaeróbios facultativos, de crescimento lento, quimiorganotróficos e são encontrados principalmente em águas poluídas (KRIEG et al., 2010).

\section{Verrucomicrobia}

O filo Verrucomicrobia abriga microrganismos gram-negativos, quimiorganotróficos (maioria) e presentes em vários ambientes, incluindo solos, lixiviados, etc. Recentemente, isolaram-se membros metanotróficos termoacidófilos (DUNFIELD et al., 2007).

Dois subfilos são de grande importância, o subfilo 3 obtido de análise do gene RNAr 16S em amostras provenientes de solo e ambientes marinhos (CRUZ-MARTINEZ et al., 2009; KRIEG et al., 2010) e o subfilo 6, predominantemente recuperado de ambientes onde ocorre a emissão de metano mostrando, portanto, evidências do consumo de metano (NIEMANN et al., 2006).

Dentro do filo Verrucomicrobia, os gêneros mais abundantes identificados foram Prostecobacter e Opitutus. Os dois gêneros são formados por microrganismos gram-negativos, quimiorganotróficos e anaeróbios (KRIEG et al., 2010).

\section{Euryarchaeota}

Dentro deste filo, o gênero Methanobacterium foi identificado com abundância relativa de $8 \%$ no inóculo, mas foi detectado com $1 \%$ de abundância após 100 dias de operação. Portanto, evidenciando que as condições de seleção e cultivo em meio autotrófico não foram favoráveis às arquéias metanogênicas. Não obstante, segundo Boetius et al. (2000), diferentes linhagens associadas com Methanosarcinales, Methanobacteriales (ANME 1, ANME 2) ou Methanococcoides (ANME 3) são responsáveis pela oxidação anaeróbia do metano (através do processo de metanogênese reversa). Portanto, a presença de arquéias metanogênicas no reator (ainda que em baixa abundância) pode indicar que estas estariam envolvidas na oxidação anaeróbia do metano (BOETIUS et al., 2000).

\section{Proteobacteria}

Dentro deste filo, identificou-se uma diversidade de microrganismos pertencentes às classes alfa, beta, gama e delta Proteobacteria, porém, apenas os microrganismos relacionados às metanotróficas foram descritos. Das 407 UTOs obtidas, 5 foram afiliadas à família Methylococcaceae (UTOs 79, 186, 251, 371, 366) e 3 estiveram relacionadas à Methylocystaceae (UTOs 94, 98 e 286). As três últimas UTOs não foram incluídas na árvore, uma vez que foram representadas por número de sequências (reads) inferior a três. A árvore filogenética afiliada ao grupo de metanotróficas está representada na Figura 6. O número de sequências recuperadas dentro de cada UTO estão indicadas entre parênteses. A barra de escala representa divergência de 10\%. O gênero Methylacidiphilum foi utilizado como outgroup. A árvore filogenética foi construída pelo método Neighbour-joining e Bootstrap para 1000 recombinações. Os valores de bootstrap (> 55\%) que suportam cada ramo estão indicados. Os nomes e número de acessos no GenBakn são apresentados na figura.

A presença de metanotróficas aeróbias em ambientes anóxicos (ou anaeróbios), como foi o caso do reator do presente estudo, foi relatada anteriormente. Ferrer et al. (2011) identificaram sequências de Methylocaldum sp. e Methylococcus em sedimentos anóxicos de um lago raso (Laguna de Carrizo, Madri, Espanha) através da análise do RNAr 16S da comunidade microbiana presente nesse sedimento. Schubert et al. (2006) também detectaram a ocorrência de células de metanotróficos tipo I em zonas anóxicas do Mar Negro. Além destes, Cvejic et al. (2000) cultivaram metanotróficos Methylocaldum tepidum e Methylocaldum szegediense em um fermentador com fluxo contínuo de metano e com concentração de oxigênio dissolvido abaixo de 5\%

Dentro da família Methylococcaceae, o gênero Methylocaldum foi detectado. Esse é formado por bactérias gram-negativas, em forma de cocos ou bacilos, arranjos simples ou diploides, moderadamente termofílicas, que crescem a temperatura até $40^{\circ} \mathrm{C}$, o que justificaria seu crescimento no reator operado a $35^{\circ} \mathrm{C}$. Estas bactérias utilizam apenas metano ou compostos de $\mathrm{C} 1$ como fonte de carbono e energia e assimilam carboidrato via Ribulose Monofosfato (LIEBERMAN \& ROSENZWEIG, 2004). A outra família Methylocystaceae é composta 
de microrganismos em formato de pequenos bastonetes a reniformes, que utilizam metano como fonte de carbono e energia e a via serina para fixação de carbono. Dentro desta família, identificou-se o gênero Methylocystis, que crescem em meio contendo sais de nitrato. Este gênero pode ser enriquecido e isolado a partir de sedimentos microaerofílicos e aeróbios de água doce, solo e amostras de esgoto (BRENNER; KRIEG; STAKEY, 2005).

\section{Consumo biológico de Nitrito e Nitrato no interior do reator em batelada sequencial}

O consumo de nitrito e nitrato é justificado principalmente pela presença de microrganismos heterotróficos desnitrificantes no interior do RBS. Dentro deste grupo, estão os microrganismos dos gêneros Pseudomonas, Clostridium, Comamonas, Acidovorax, Variovorax assim como vários outros gêneros das famílias Bradyrhizobiaceae, Comamonadaceae, Acetobacteraceae, Rhodocyclaceae e ordem Rhodospirillales. A maioria das bactérias desnitrificantes são anaeróbias facultativas e quimiorganotróficas (MAC CONELL, 2014).

Conforme já mencionado, a presença de arquéias também poderia contribuir para o consumo de nitrato. Além desses, a presença de microrganismos facultativos como Thermomonas (redução de nitrato a nitrito) e Pseudoxanthomonas (redução de nitrito a óxido nitroso) também foram identificados. O gênero Nitrospira, que compreende bactérias aeróbias autotróficas responsáveis pela oxidação de nitrito a nitrato, também foi detectado. Em estudos anteriores, Nitrospira, foi detectada em reatores anammox, portanto, sob condições anaeróbias (COSTA et al., 2014; PEREIRA et al., 2014).

\section{Determinação da taxa de consumo de metano e atividade metanotrófica}

A taxa de consumo de metano para as amostras do inóculo e amostra do reator após 191 dias de cultivo, foi determinada conforme descrito na metodologia. A Figura 7 mostra os valores da taxa de decaimento de metano nos dois ensaios realizados, utilizando-se como base os valores da mediana. Pode-se observar que, para as amostras do inóculo e biomassa do reator, os valores da taxa de consumo de metano por dia foram, respectivamente, 0,6 mL.CH ${ }_{4} \cdot \mathrm{dia}^{-1}$ e $0,8 \mathrm{~mL} \cdot \mathrm{CH}_{4} \cdot \mathrm{dia}^{-1}$ (Tabela 2). A atividade metanotrófica para ambas as amostras também foi calculada e é apresentada na Tabela 2. Verificou-se que a atividade metanotrófica

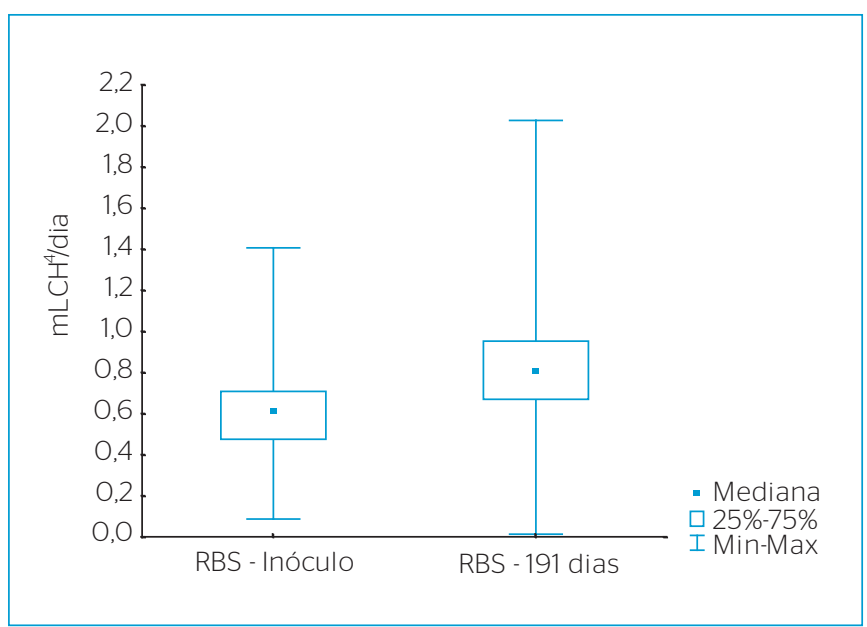

Figura 7 - Diagrama Box-plot mostrando a taxa de decaimento de $\mathrm{CH}_{4}$ para o inóculo e biomassa do reator em batelada sequencial após 191 dias de operação.

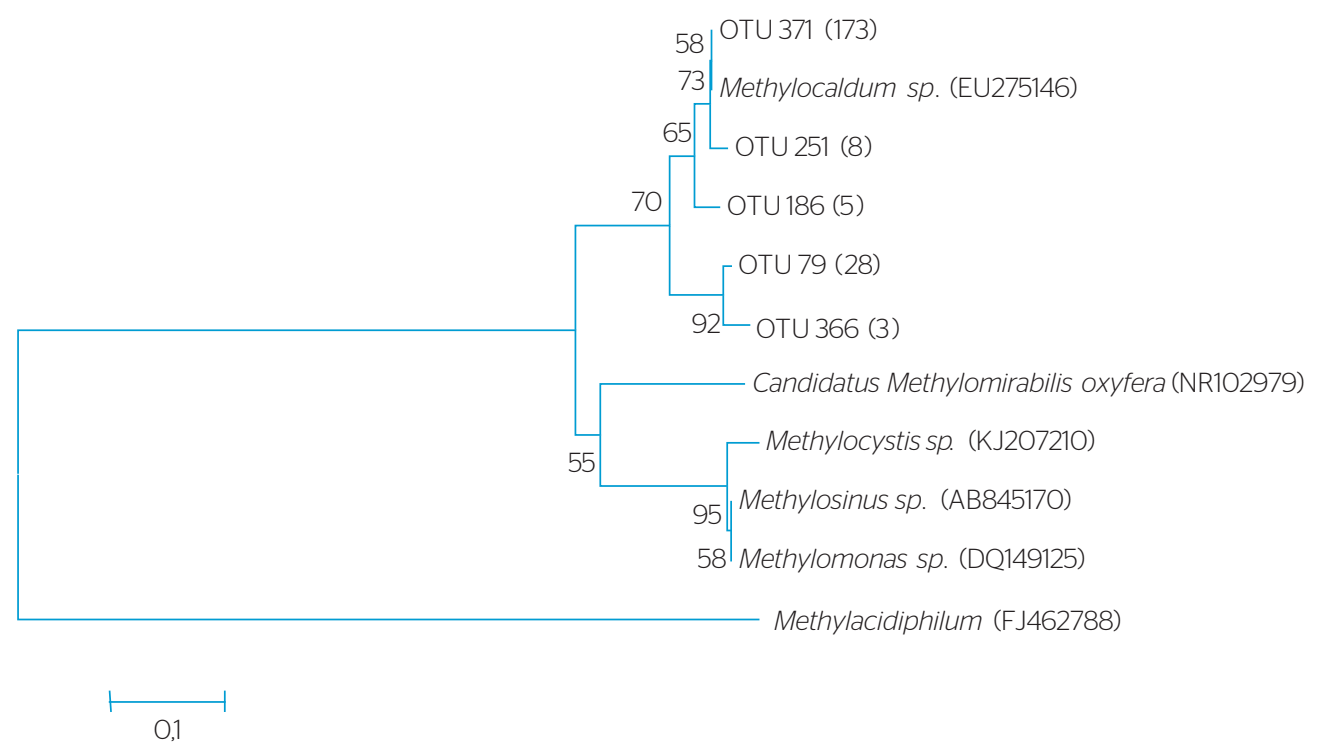

Figura 6 - Árvore filogenética das unidades taxonômicas operacionais relacionadas às sequências de bactérias metanotróficas. 
Tabela 2 - Mediana da taxa de consumo de metano e Atividade Metanotrófica das amostras.

\begin{tabular}{|c|c|c|c|c|c|}
\hline \multirow{2}{*}{ Amostra } & Taxa de consumo $\mathrm{CH}_{4}$ & STV & Volume & g.STV & Atividade Metanotrófica \\
\hline & $\left(\mathrm{mL} . \mathrm{CH}_{4} \cdot \mathrm{dia}^{-1}\right)$ & $\left(g \cdot L^{-1}\right)$ & $(\mathrm{mL})$ & (Biomassa) & $\left(\mathrm{mLCH}_{4} / \mathrm{gSTV} . \mathrm{dia}^{-1}\right)$ \\
\hline Inóculo & 0,6 & 5,0 & 20 & 0,1 & 6,0 \\
\hline Biomassa RBS & 0,8 & 2,3 & 20 & 0,046 & 17,3 \\
\hline
\end{tabular}

*Os cálculos da taxa de consumo estão detalhados na metodologia; RBS: reator em batelada sequencial.

da amostra retirada do reator foi quase que três vezes maior quando comparada com a atividade metanotrófica do inóculo, sugerindo que houve seleção e enriquecimento de biomassa oxidadora de metano no reator a partir das condições de cultivo fornecidas, e, portanto maior atividade metanotrófica foi medida na amostra do reator.

\section{CONCLUSÕES}

O cultivo de microrganismos metanotróficos a partir de lodo de UASB como inóculo em RBS foi realizado com sucesso. A fase inicial de enriquecimento e cultivo (100 primeiros dias) foi distinta dos demais períodos de operação do reator e foi marcada pelo consumo intenso de nitrito e nitrato evidenciando atividade de desnitrificação heterotrófica. A presença de ANME foi confirmada para os períodos
P1 e P2 de operação do reator. Os filos mais abundantes identificados nas amostras a partir do pirosequenciamento foram Planctomycetes, Verrucomicrobia, Chloroflexi e Proteobacteria. Gêneros relacionados à arquéias (Methanobacterium) e bactérias metanotróficas (Methylocaldum, Methylocistis e Methylosinus) foram identificados na biomassa do reator após 100 dias de operação, indicando que as condições de cultivo foram seletivas, favorecendo esses grupos. A atividade metanotrófica da biomassa do reator após 191 dias de cultivo foi quase três vezes maior que a atividade metanotrófica do lodo de inóculo. Portanto, esses resultados indicam que o inóculo utilizado (lodo de UASB) bem como as condições de cultivo empregadas foram adequadas para promover a seleção e enriquecimento de microrganismos metanotróficos, porém, metanotróficos desnitrificantes (relacionados ao filo NC10) ainda não foram detectados.

\section{REFERÊNCIAS}

AMERICANPUBLIC HEALTHASSOCIATION-APHA.(2005)Standard Methods for the Examination of Water and Wastewater 21 ed. Washington, DC, USA.

BARNES, R.O. \& GOLDBERG, E.D. (1976) Methane production and consumption in anoxic marine sediments. Geology, v. 4, n. 5, p. 297-300.

BOETIUS, A.; RAVENSCHLAG, K.; SCHUBERT, C.J.; RICKERT, D.; WIDDEL, F.; GIESEKE, A.; AMANN, R.; JORGENSEN, B.B.; WITTE, U.; PFANNKUCHE, O. (2000) A marine microbial consortium apparently mediating anaerobic oxidation of methane. Nature, v. 407, n. 6804, p. 623-626

BOGNER, J; PIIPATTI, R; HASHIMOTO, S; DIAZ, C; MARECKOVA, K; DIAZ, L; KJELDSEN, P; MONNI, S; FAAIJ, A; GAO, Q; ZHANG, T; AHMED, M. A; SUTAMIHARDJA, R.T; GREGORY, R. (2008) Mitigation of global greenhouse gas emissions from waste: conclusions and strategies from the Intergovernmental Panel on Climate Change (IPCC) Fourth Assessment Report. Working Group III (Mitigation). Waste Management \& Research, v. 26, p. 11-32.

BOWMAN, J.P.; SLY, L.I.; STACKEBRANDT, E. (1995) The phylogenetic position of the family Methylococcaceae. Internacional Journal of Systematic and Evolucionary Microbiology, v. 45, p. 182-185.

BRENNER, D.J.; KRIEG, N.R.; STAKEY, J.T. (2005) Bergey's manual of systematic bacteriology. Vol. Two. The Proteobacteria - Part B: Gammaproteobacteria USA: Springer.
CAKIR, F.Y. \& STENSTROM, M.K. (2005) Greenhouse gas production: A comparison between aerobic and anaerobic wastewater treatment technology. Water Resourch, v. 39, p. 4197-4203.

CAPORASO, G.; KUCZYNSKI, J.; STOMBAUGH, J.; BITTINGER, K.; BUSHMAN, F.; COSTELLO, E.; FIERER, N.; PENA, A.; GOODRICH, J.; GORDON, J.; HUTTLEY, Y. G.; KELLEY, S.; KNIGHTS, D.; KOENIG, J.; LEY, R.; LOZUPONE, C.; MC DONALD, D.; MUEGGE, B.; PIRRUNG, M.; REEDER, J.; SEVINSKY, J.; TURNBAUGH, P.; WALTERS, W.; WIDMANN, J.; YATSUNENKO, T.; ZANEVELD, J.; KNIGHT, R. (2O1O) QIIME allows analysis of high-throughput community sequencing data. Nature Methods, v. 7, p. 335-336.

CARDINALI-REZENDE, J:; ARAÚJO, J.C.; ALMEIDA, P.G.S.; CHERNICHARO, C.A.L.; SANZ, J.L.; CHARTONE-SOUZA, E.; NASCIMENTO, A.M.A. (2013) Organic loading rate and food-to-microorganism ratio shape prokaryotic diversity in a demo-scale up-flow anaerobic sludge blanket reactor treating domestic wastewater. Antonie van Leeuwenhoek, v. 104, n. 6, p. 993-1003.

CHERNICHARO, C.A. (2007) Princípios do tratamento biológico de águas residuárias: Reatores anaeróbios. 2 edição. Departamento de Engenharia Sanitária e Ambiental - DESA/UFMG, Belo Horizonte: Editora UFMG. 380 p. 
COSTA, M.C.; CARVALHO, L.; LEAL, C.D.; DIAS, M.F.; MARTINS, K.L.; GARCIA, G.B.; MANCUELO, I.D.; HIPÓLITO, T.; MAC CONELL, E.F.A.; OKADA, D.; ETCHEBEHERE, C.; CHERNICHARO, C.A.; ARAÚJO, J.C. (2014) Impact of inocula and operating conditions on the microbial community structure of two anammox reactors. Environmental Technology, v. 35, p. 1811-1822.

CRUZ-MARTINEZ, K.; SUTTLE, K.B.; BRODIE, E.L.; POWER, M.E.; ANDERSEN, G.L.; BANFIELD, J.F. (2009) Despite strong seasonal responses, soil microbial consortia are more resilient to long-term changes in rainfall than overlying grassland. ISME Journal, v. 3, p. 738-744.

CVEJIC, J.H.; BODROSSY, L.; KOVÁCS, K.L.; ROHMER, M. (2000) Bacterial triterpenoids of the hopane series from the methanotrophic bacteria Methylocaldum spp:: phylogenetic implications and first evidence for an unsaturated aminobacteriohopanepolyol. FEMS Microbiology Letters, v. 182, p. 361-365.

DONACHIE, S.P.; HOU, S.; LEE, K.S. (2004) The Hawaiian archipelago: a microbial diversity hotspot. Microbial Ecology, v. 48, p. 509-520.

DUNFIELD, P.F.; YURYEV, A.; SENIN, P.; SMIRNOVA, A.V.; STOTT, M.B.; HOU, S.; LY, B.; SAW, J.H.; ZHOU, Z.; REN, Y.; WANG, J.; MOUNTAIN, B.W.; CROWE, M.A.; WEATHERBY, T.M.; BODELIER, P.L.; LIESACK, W.; FENG, L.; WANG, L.; ALAM, M. (2007) Methane oxidation by an extremely acidophilic bacterium of the phylum Verrucomicrobia. Nature, v. 450, p. 879-882.

EDGAR, R.C. (2010) Search and clustering orders of magnitude faster than BLAST. Bioinformatics, v. 26, p. 2460-2461.

EGLI, K.; LANGER, C.; SIEGRIST, H.R.; ZEHNDER, A.J.B.; WAGNER, M.; VAN DER MEER, J.R. (2003) Community Analysis of Ammonia and Nitrite Oxidizers during Start- Up of Nitritation Reactors. Applied and Environmental Microbiology, v. 69, n. 6, p. 3213-3222.

ETTWIG, K.F.; SHIMA, S.; VAN DE PAS-SCHOONEN, K.T.; KAHNT, J.; MEDEMA, M.H.; OP DEN CAMP, H.J.; JETTEN, M.S.; STROUS, M. (2OO8) Denitrifying bacteria anaerobically oxidize methane in the absence of Archaea. Environmental Microbiology, v. 10, n. 11, p. 3164-3173.

ETTWIG, K.F.; VAN ALEN, T.; VAN DE PAS-SCHOONEN, K.T.; JETTEN, M.S.; STROUS, M. (2009) Enrichment and molecular detection of denitrifying methanotrophic bacteria of the NC1O phylum. Applied and Environmental Microbiology, v. 75, n. 11, p. 3656-3662.

FERRER, M.; GUAZZARONI, M.-E.; RICHTER, M.; GARCIA-SALAMANCA, A.; YARZA, P.; SUÁREZ-SUÁREZ, A.; SOLANO, J.; ALCAIDE, M.; DILLEWIJN, P. V.; MOLINA-HENARES, M. A.; LÓPEZ-CORTÉS, N.; AL-RAMAHI, Y.; GUERRERO, C.; ACOSTA, A.; EUGENIO, L.I.D.; MARTÍNEZ, V.; MARQUES, S.; ROJO, F.; SANTERO, E.; GENILLOUD, O.; PÉREZ-PÉREZ, J.; ROSSELLÓ-MÓRA, R.; RAMOS, J.L. (2O11) Taxonomic and Functional Metagenomic Profiling of the Microbial Community in the Anoxic Sediment of a Sub-saline Shallow Lake (Laguna de Carrizo, Central Spain). Microbial Ecology, v. 62, n. 4, p. 824-837.

GANESAN, A.; CHAUSSONNERIE, S.; TARRADE, A.; DAUGA, C:; BOUCHEZ, T.; PELLETIER, E.; LE PASLIER, D.; SGHIR, A. (2008) Cloacibacillus evryensis gen. nov., sp. nov., a novel asaccharolytic, mesophilic, amino-acid-degrading bacterium within the phylum 'Synergistetes', isolated from an anaerobic sludge digester. Internacional Journal of Systematic and Evolutionary Microbiology, v. 58, p. 2003-2012.
GARCIA, P.P.G. (2009) Caracterização dos microrganismos oxidadores de sulfeto e metano em reator UASB. (Dissertação de Mestrado). Programa de Pós Graduação em Saneamento, Meio Ambiente e Recursos Hídricos, DESA, UFMG, Belo Horizonte.

HANSON, R.S. \& HANSON, T.E. (1996) Methanotrophic bacteria. Microbiology and Molecular Biology Reviews, v. 60, n. 2, p. 439-471.

HINRICHS, K.U.; HAYES, J.M.; SYLVA, S.P.; BREWER, P.G.; DELONG, E.F. (1999) Methane-consuming archaebacteria in marine sediments. Nature, v. 398, n. 6730, p. 802-805.

HOLMES, A.J.; COSTELLO, A.; LINDSTROM, M.E.; MURRELL, J.C. (1995) Evidence that particulate methane monooxygenase and ammonia monooxygenase may be evolutionary related. FEMS Microbiol ogy Letters, v. 132, p. 203-208.

HU, S.; ZENG, R.J.; BUROW, L.C.; LANT, P.; KELLER, J.; YUAN, Z. (2009) Enrichment of denitrifying anaerobic methane oxidizing microorganisms. Environmental Microbiology Reports, v. 1, n. 5, p. 377-84.

KNITTEL, K. \& BOETIUS, A. (2009) Anaerobic Oxidation of Methane: Progress with an Unknown Process. Annual Review of Microbiology, v. 63, p. $311-334$.

KRIEG, N.R.; STALEY, J.T.; BROWN, D.R.; HEDLUND, B.P.; PASTER, B.J; WARD, N.L.; LUDWIG, W.; WHITMAN, W.B. (2010) Bergey's manual of systematic bacteriology. Vol. Four. The Bacteroidetes, Spirochaetes, Tenericutes (Mollicutes), Acidobacteria, Fibrobacteres, Fusobacteria, Dictyoglomi, Gemmatimonadetes, Lentisphaerae, Verrucomicrobia, Chlamydiae and Planctomycetes. Second. United States: Springer

LECLERC, M.; CÉLINE, D; RENÉ, M.; JEAN-JACQUES, G. (2001) Single strand conformation polymorphism monitoring of 165 rDNA Archaea during start-up of an anaerobic digester. FEMS Microbiology Ecology, v. 34, n. 3, p. 213-220

LECLERC, M.; DELGĖNES, J.P.; GODON, J.J. (2004) Diversity of the archaeal community in 44 anaerobic digesters as determined by single strand conformation polymorphism analysis and 16S rDNA sequencing. Environmental Microbiology, v. 6, n. 8, p. 809-819.

LEE, J.H.; KIM, T.G.; CHO, K.S. (2012) Isolation and characterization of a facultative methanotroph degrading malodor-causing volatile sulfur compounds. Jornal of Hazardous Materials, v. 15, n. 235-236, p. 224-229.

LIEBERMAN, R.L. \& ROSENZWEIG, A.C. (2004) Biological Methane Oxidation: Regulation, Biochemistry, and Active Site Structure of Particulate Methane Monooxygenase. Critical Reviews in Biochemistry and Molecular Biology, v. 39, p. 147-164

LIEBNER, S. \& WAGNER, D. (2007) Abundance, Distribution and Potential Activity of Methane Oxidising Bacteria in Permafrost Soils from the Lena Delta, Siberia. Environmental Microbiology, v. 9, n. 1, p. 107-117.

LUESKEN, F.A. (2011) Applied aspects of nitrite-dependent methane oxidation. 124p. (Tese de doutorado). Radboud University Nijmegen, Netherlands.

LUESKEN, F.A.; VAN ALEN, T.A.; VAN DER BIEZEN, E.; FRIJTERS, C.; TOONEN, G.; KAMPMAN, C.; HENDRICKX, T.L.; ZEEMAN, G.; TEMMINK, H.; STROUS, M.; OP DEN CAMP, H.J.; JETTEN, M.S. (2O11a) Diversity and enrichment of nitrite-dependent anaerobic methane oxidizing bacteria from wastewater sludge. Applied Microbiology and Biotechnology, v. 92, n. 4, p. 845-854. 
LUESKEN, F.A.; ZHU, B.; ALEN, T.; BUTLER, M.K.; DIAZ, M. R.; SONG, B.; OP DEN CAMP, H.J.; JETTEN, M.S.; ETTWIG, K.F. (2O11b) pmoA Primers for Detection of Anaerobic Methanotrophs. Appl Environ Microbiol, v. 77, p. 3877-3880.

MAC CONELL, É.F.A. (2014) Caracterização da comunidade bacteriana de filtros biológicos percoladores tratando efluente anaeróbio. (Tese de Doutorado). Departamento de Engenharia Sanitária e Ambiental, Universidade Federal de Minas Gerais, Belo Horizonte.

MCDONALD, I.R.; UPTON, M.; HALL, G.; PICKUP, R.W.; EDWARDS, C.; SAUNDERS, J.R.; RITCHIE, D.A.; MURREL, J.C. (1999) Molecular ecological analysis of methanogens and methanotrophs in blanket bog peat. Microbial Ecology, v. 38, n. 3, p. 225--233.

MEULEPAS, R.J.W.; JAGERSMA, C.G.; ZHANG, Y.; PETRILLO, M.; CAI, H.Z.; BUISMAN, C.J.N.; STAMS, A.J.M.; LENS, P.N.L. (2010) Trace methane oxidation and the methane dependency of sulfate reduction in anaerobic granular sludge. FEMS Microbiology Ecology, v. 72, n. 2 , p. $261-271$.

NAUHAUS, K:; TREUDE, T.; BOETIUS, A.; KRUGER, M. (2005) Environmental regulation of the anaerobic oxidation of methane: a comparison of ANME-I and ANME-II communities. Environmental Microbiology, v. 7, n. 1, p. 98-106.

NIEMANN, H.; LOSEKANN, T.; DE BEER, D.; ELVERT, M.; NADALIG, T.; KNITTEL, K.; AMANN, R.; SAUTER, E.J.; SCHLUTER, M.; KLAGES, M.; FOUCHER, J.P.; BOETIUS, A. (2006) Novel microbial communities of the Haakon Mosby mud volcano and their role as a methane sink. Nature, v. 443, p. $854-858$.

ORPHAN, V.J.; HOUSE, C.H.; HINRICHS, K.U.; MCKEENGANS, K.D.; DELONG, E.F. (2002) Multiple archaeal groups mediate methane oxidation in anoxic cold seep sediments. Microbiology, v. 99, n. 11, p. 7663-7668.

PEREIRA, A.D.; LEAL, C.D.; DIAS, M.F.; ETCHEBEHERE, C.; CHERNICHARO, C.A.L.; ARAÚJO, J.C. (2014) Effect of phenol on the nitrogen removal performance and microbial community structure and composition of an anammox reactor. Bioresource Technology, v. 166, p. 103-111.

RAGHOEBARSING, A.A.; POL, A.; PAS-SCHOONEN, K.T.V.D.; SMOLDERS, A.J.P.; ETTWIG, K.F.; RIJPSTRA, W.I.C.; SCHOUTEN, S.; DAMST, J.S.S.; CAMP, H.J.M.O.D.; JETTEN, M.S.M.; STROUS, M. (2006) A microbial consortium couples anaerobic methane oxidation to denitrification. Nature, v. 440, n. 7086, p. 918-921.

RASKIN, L.; STROMLEY, J.M.; RITTMANN, B.E.; STAHL, D.A. (1994) Group-specific 16S rRNA hybridization probes to describe natural communities of methanogens. Applied and Environmental Microbiology, v. 60, n. 4, p. 1232-1240.
REEBURGH, W.S. (2007) Oceanic methane biogeochemistry. Chemical Reviews, v. 107, n. 2, p. 486-513.

SCHUBERT, C.J.; COOLEN, M.J.L.; NERETIN, J.N.; SCHIPPERS, A.; ABBAS, B.; DURISCH-KAISER, E.; WEHRLI, B.; HOPMANS, E.C.; DAMSTÉ, J.S.S.; WAKEHAM, J.; KUYPERS, M.M.M. (2006) Aerobic and anaerobic methanotrophs in the Black Sea water column. Environmental Microbiology, v. 8, n. 10, p. 1844-1856.

SILVA, M.R.L. (2012) Caracterização da comunidade microbiana de biofilme anaeróbio em presença de bifenilas policloradas.107 (Dissertação de Mestrado). Programa de Engenharia Hidráulica e Saneamento, Universidade de São Paulo, São Carlos.

SMEMO, K.A. \& YAVITT, J.B. (2011) Anaerobic oxidation of methane: an underappreciated aspect of methane cycling in peatland ecosystems? Biogeosciences, v. 8, p. 779-793.

SOUZA, C.L. \& CHERNICHARO, C.A.L. (2011) Methane losses in UASB reactors treating domestic wastewater: mass balance and possible improvements. Proc. 10th IWA specialist conference on small water and wastewater treatment systems. Venice, Italia.

TAMURA, K.; DUDLEY, J.; NEI, M.; KUMAR, S. (2007) MEGA 4: Molecular Evolutionary Genetics Analysis (MEGA) software version 4.0. Molecular Biology and Evolution, v. 24, p. 1596-1599.

TESSARO, S. (2012) Estudo da comunidade de bactérias metanotróficas em uma cronossequência de solos da Amazônia. (Master of Science). Instituto de Ciências Biomédicas, Universidade de São Paulo, São Paulo.

THOMSEN, T.R.; FINSTER, K.; RAMSING, N.B. (2001) Biogeochemical and molecular signatures of anaerobic methane oxidation in a marine sediment. Applied and Environmental Microbiology, v. 67, p. 1646-1656.

VALENTINE, D.L. (2002) Biogeochemistry and microbial ecology of methane oxidation in anoxic environments: a review. Antonie van Leeuwenhoek, v. 81, n. 1-4, p. 271-282.

VOS, P.D.; GARRITY, G.M.; JONES, D.; KRIEG, N.R.; LUDWIG, W.; RAINEY, F.A.; SCHLEIFER, K.H.; WHITMAN, W.B. (2009) Bergey's manual of systematic bacteriology. Vol. Three. The Firmicutes. Second edition, Springer, USA.

WANG, X.; HU, M.; XIA, Y.; WEN, X.; DING, K. (2012) Pyrosequencing analysis of bacterial diversity in 14 wastewater treatment systems in China. Applied and Environmental Microbiology, v. 78, n. 19, p. 7042-7047.

WHITTENBURY, R. \& KRIEG, N.R. (1984) Methylococcacea fam. nov., In N. R. Krieg and J. G. Holt (ed.), Bergey's manual of systematic bacteriology. Baltimore. 